\title{
УСИЛЕНИЕ РОЛИ ЛЕСНОГО ПОТЕНЦИАЛА МАЛОЛЕСНЫХ РЕГИОНОВ РФ ДЛЯ ПОВЫШЕНИЯ ТЕМПОВ СОЦИАЛЬНО-ЭКОНОМИЧЕСКОГО РАЗВИТИЯ И СБАЛАНСИРОВАННОСТИ ИНТЕРЕСОВ НАСЕЛЕНИЯ, БИЗНЕСА И АДМИНИСТРАТИВНЫХ СТРУКТУР
}

STRENGTHENING THE ROLE
OF THE FOREST POTENTIAL
OF LOW-FOREST REGIONS
OF THE RUSSIAN FEDERATION
TO INCREASE THE PACE
OF SOCIO-ECONOMIC DEVELOPMENT
AND BALANCE THE INTERESTS
OF THE POPULATION, BUSINESS
AND ADMINISTRATIVE STRUCTURES
Summary. Forest deficient regions of the Russian Federation, which are
located mainly in the European part of the Russian Federation, are included
in the steppe and forest-steppe zones of our country. On the example of
the Orenburg, Samara and Saratov regions of the Volga Federal District,
which have a low forest cover, the possibilities of enhancing the role of the
forest potential due to the intensification of recreational and protective
forest management, streamlining the spatial organization of agroforest
landscapes are shown. It justifies the need for agricultural producers of
various forms of ownership to create new and reconstruction of existing
agroforestry objects. It is proposed, on the basis of neural network tools,
to develop models for the rational distribution of economic entities and
the development of a regional economic space for the constituent entities
of the Russian Federation, which allow balancing the pace and scale of
modernization of both technogenic and socio-natural subsystems in
order to increase the combined synergetic effect in the interests of the
population, business and territorial governance structures.
Keywords: forest potential, forest cover of the territory, agroforest
landscapes, regional economic space.
Nitiknomirov

\author{
Кожухов Николай Иванович \\ Академик РАН, д.э.н., профессор, независимый \\ Исследователь \\ Тихомиров Евгений Александрович \\ К.э.н., дочент, МФ Московский государственный \\ технический университет им. Н.Э. Баумана \\ tihomirov@mgul.ac.ru
}

Аннотация. Лесодефицитные регионы Российской Федерации, которые размещены преимущественно в Европейской части РФ, входят в степную и лесостепную зоны нашей страны. На примере Оренбургской, Самарской и Саратовской областей Приволжского федерального округа, имеющих низкий уровень лесистости, показаны возможности усиления роли лесного потенциала за счет интенсификации рекреационного и защитного лесопользования, упорядочивания пространственной организации агролесных ландшафтов. Обосновывается необходимость для сельскохозяйственных производителей различных форм собственности создания новых и реконструкция действующих агролесомелиоративных объектов. Предлагается на базе нейросетевых инструментов разрабатывать для субъектов РФ м0дели рационального размещения хозяйствующих субъектов и развитие регионального экономического пространства, позволяющие сбалансировать темпы и масштабы модернизации как техногенной, так и социоприродной подсистем, чтобы повысить совокупный синергетический эффект в интересах населения, бизнеса и территориальных структур управления.

Ключевые слова: лесной потенциал, лесистость территории, агролесные ландшафты, региональное экономическое пространство. 
Таблица 1. Характеристика лесных территорий и запасов древесины в трех субъектах ПФО

\begin{tabular}{|l|l|l|l|l|l|l|}
\hline Субъекты РФ & $\begin{array}{l}\text { Общая пло- } \\
\text { щадь земель } \\
\text { ЛФ, тыс. Га }\end{array}$ & $\begin{array}{l}\text { Леса, не входя- } \\
\text { фонд, тыс. Га }\end{array}$ & $\begin{array}{l}\text { Лесные зем- } \\
\text { ли., тыс. Га }\end{array}$ & $\begin{array}{l}\text { Земли, покры- } \\
\text { тые лесом,, тыс. } \\
\text { Га }\end{array}$ & $\begin{array}{l}\text { Общий запас } \\
\text { древесины. млн. } \\
\text { м }^{3}\end{array}$ & $\begin{array}{l}\text { Общий сред- } \\
\text { ний прирост, } \\
\text { млн. м³ }\end{array}$ \\
\hline Оренбургская область & 696,5 & 27,9 & 590,2 & 563,9 & 70,14 & 1,44 \\
\hline Самарская область & 764,5 & 15,5 & 704,5 & 682,6 & 94,93 & 1,92 \\
\hline Саратовская область & 712,6 & 27,3 & 646,5 & 603,3 & 59,66 & 1,28 \\
\hline
\end{tabular}

$\boldsymbol{л}$ есной кодекс РФ, введённый в действие в конце декабря 206 года, передал функции хозяйственного управления землями лесного фонда с федерального на региональный уровень [7].

За более чем десятилетний период применения на практике положений этого документа, даже с учетом многочисленных дополнений и изменений отдельных статей Кодекса, выявились некоторые принципиально важные элементы этого правового документа, требующие серьёзной корректировки $[1,10]$.

В этой связи начата работа по формированию новой редакции Лесного Кодекса РФ, которую планируется завершить в 2020 году.

Как известно, в Стратегию 2020 [11] основные положения которой направленны на обеспечение долгосрочного устойчивого социально-экономического развития России и ее регионов, была заложена задача сбалансирования интересов государства, населения и бизнеса, функционирующего в региональном экономическом пространстве.

Лесной потенциал РФ, как в многолесной зоне, так и в регионах страны, малообеспеченных лесными ресурсами, нередко выступает в качестве звена регионального пространства. В многолесной зоне нашей страны за счет использования и воспроизводства сырьевых ресурсов леса, в лесодефицитных районах за счет рекреационного и защитного лесопользования. Для местного населения, и особенно, живущего в так называемой «российской глубинке», леса являются частью социально-культурного и экологического благополучия, источником экономических элементов жизнедеятельности.

Значительно выросшая в стране экологическая грамотность населения, способствует бережному отношению к лесам, окружающей природной среде и росту требований к усилению роли лесного потенциала в регионально экономическом пространстве. Основные аспекты таких требований должны найти отображение в Лесном кодексе РФ.

Рассматривая уровень обеспеченности лесными ресурсами субъектов РФ, входящих в Приволжский фе- деральный округ, можно отметить, что несмотря на достаточно высокий средний уровень лесистости этого округа, равный 36,5\%, минимальный уровень этого показателя имеют лишь Оренбургская (4,6\%) и Саратовская (6\%) области [8]. Самарская область, при её. казалось бы, неплохом показателе лесистости (отношение площади лесов к общей площади области) равным 12,7\%, также является лесодефицитным субъектом РФ.

В таблице 1 приведены краткие сведения о лесном фонде и лесах, не входящих в лесной фонд, перечисленных субъектов РФ.

Все леса, указанных областей, относятся к категории защитных лесов. Преобладают молодые и средневозрастные насаждения. Во всех трех областях основными лесообразующими породами являются лиственные: дуб, липа, берёза, осина. Хвойные древостои представлены сосной и занимают от 13 до 14\% лесопокрытой площади [8].

Леса, не входящие в лесной фонд, представлены в основном городскими лесами. Кроме лесных земель в лесном фонде имеются незначительные площади нелесных земель - это сенокосы и заболоченные территории.

Информация, представленная в таблице 1 свидетельствует о низком уровне развития лесного потенциала, его незначительной роли в социально экономической сфере данных субъектов РФ.

Все три области находятся в степной зоне. Лишь незначительная часть северных территорий каждой из данных областей затрагивает лесостепную зону в Российской Федерации. Один из «островков» соснового бора в южной части лесостепи - Бузулукский бор площадью 7,2 Га расположен как в Оренбургской (преимущественно). так и в Самарской областях.

Тем не менее, возможностях по усилению роли лесного потенциала в рассматриваемом регионе имеются. Прежде всего следует исходить из необходимости повышения уровня лесистости каждого из указанных субъектов Российской Федерации за счёт создания новых и реконструкции действующих адрес агролесомелиора- 
тивных объектов: полезащитных лесных полос, противоэрозионных насаждений по оберегам водоемов, вокруг оврагов и балок, ветрозащитных и снегозадерживающих лесных полос.

Наступил период, когда окрепшие фермерские хозяйства и сельхозпредприятия могут позволить себе возобновить ранее проводившуюся регулярную работу по формированию системы агролесомелиоративных мероприятий. Такая работа вполне логично приведет к упорядочиванию пространственной организации агролесных ландшафтов [2].

Наряду с увеличением площади защитных лесонасаждений, которые способствуют заметному приросту урожайности сельскохозяйственных культур [5]. значительный эффект может быть получен и за счет интенсификации рекреационного лесопользования.

В степных районах Оренбургской и Самарской областей имеется ощутимая потребность в создании искусственных водоемов, на базе современных технологий, не допускающих чрезмерной фильтрации воды, формирования вокруг них зелёных зон для рекреантов. Настоящий «оазис», сформированный в Каменной степи (Павловский район Воронежской области), показал огромную силу воздействия как на окружающую природную среду, так и на социально-культурные, а также экономическое представление общества о реальных достижениях неравнодушных к природе людей [5].

Рекреационный потенциал всех вышеназванных областей ПФО, даже при незначительных площадях лесного фонда, может быть увеличен на базе частно-государственного партнёрства и стимулирования темпов роста инвестиций в сферу рекреационных услуг за счёт грамотного администрирования на местах, снижения налоговой нагрузки на малый бизнес и других средств поддержки инициативных предпринимателей.

Развитие прудового рыбоводства и создание мест отдыха для любителей рыбной ловли, организация летнего отдыха для детей и взрослых в кемпингах и палаточных «биваках», организация пунктов для сбора и переработки пищевых и лекарственных недревесных продуктов леса - далеко не полный перечень многообразных направлений рекреационных услуг.

До сих пор слабо задействован механизм использования защитных услуг лесного хозяйства для сельхозпроизводителей, как с точки зрения оплаты этих услуг, так и в отношении проектирования, авторского надзора и организации выполнения агролесомелиоративных проектов.
Повышение уровня использования и расширенного воспроизводства лесного потенциала малолесных регионов невозможно в отрыве от комплексной модели развития регионального экономического пространства. В настоящее время, когда Россия уверенно включилась В процесс модернизации производительных сил на этапе шестого технологического уклада [9], имеется возможность для каждого субъекта Российской Федерации на базе нейросетевых инструментов, разрабатывать модель рационального развития природно-ресурсного потенциала региона.

При таком подходе к эффективному управлению региональном экономическим пространством, исключается проблема некомплексного, разбалансированного развития территории, возрастает конкурентный потенциал региона. Оптимизируя параметры развития экономического пространства каждого субъектов РФ, необходимо учитывать местные специфические особенности произрастания лесов, социально-культурные модели отношения населения к использованию и воспроизводству лесных ресурсов всех видов: древесины, недревесных продуктов леса, рекреационному и защитному потенциалу лесов.

В интересах достижения цели устойчивого развития Оренбургский, Самарской и Саратовской областей, целесообразно сбалансировать интересы и темпы развития как техногенной, так и природной подсистем, чтобы повысить совокупную эколого-экономическую эффективность [2].

Доля увеличения вклада лесного потенциала в социально-экономическое развитие данных областей ПФО, необходимо более тесное сотрудничество смежных органически взаимосвязанных отраслей - сельского и лесного хозяйства при формировании агролесных ландшафтов. Адаптивно-ландшафтная система земледелия, хорошо зарекомендовавшая себя в ряде регионов малолесной зоны Российской Федерации, ориентирует сельхоз товаропроизводителей к оптимизации пространственной организации агролесных ландшафтов и стимулирует создание необходимых агролесомелиоративных объектов [5].

Повысить уровень лесистости Оренбургской и Самарской областей на 2-3\% возможно за счет лесоразведения на неудобных для сельхоза работ землях, при реализации противоэрозионных проектов, создании лесозащитных полос вдоль транспортных магистралей. Исходя из условий местопроизрастания для древесных пород этой зоны, наиболее приемлемая схема создания лесных полос путем чередования рядов дуба и липы. Как правило, достаточно 6-8 рядов основных древесных пород, которые оконтурены 
с обеих сторон засухоустойчивыми рядами кустарников.

На неудобных для обработки и ухода за сельскохозяйственными культурами средствами малой механизации землях, следует создавать биогруппы древесных пород, ориентируясь на специфику местного ландшафта и эстетические критерии. Состав древесных пород биогруппы может представлен березой, липой, дубом и единичным экземплярами сосны, а также декоративными кустарниками.

В идеале для осуществления подобного рода масштабных работ, следует разработать региональную целевую комплексную программу лесоразведения в степной зоне ПФО, которая может стать частью будущего национального проекта. В рамках такой программы можно предусмотреть создание лесопитомника для выращивания сеянцев дуба из элитных желудей, получаемых в процессе генетических и селекционных работ [4].

Исходя из классического опыта отечественного лесоразведения в степной зоне [5], в основу стратегии и тактики реализации таких проектов закладывается принцип сбалансированности как возможностей, так и объективно существующих ограничений в региональном экономическом пространстве. Однако, следует учитывать. что преобразования, направленные на оптими- зацию пространственной организации хозяйствующих структур региона, например, агролесных ландшафтов сельхоз организаций, создают условия для получения заметного эффекта, к тому же обладающего всеми признаками синергизма $[4,5]$.

При этом четко проявляют себя такие элементы синергического эффекта, как социально-экологический синергизм, инвестиционно-финансовый синергизм межотраслевой интеграции и кооперации, оперативно-тактический синергизм. Интегральный эффект самоорганизующейся системы и метод определения совокупного синергического представлены в работе [4].

Россия вступила в эпоху серьезных перемен, невзирая на мировою пандемию COVID-19 и связанные с ней негативные эффекты и последствия, появились новые управленческие кадры, меняются в лучшую сторону структуры органов управления на федеральном уровне, стабилизируются финансово-экономические механизмы, что дает основание ожидать в перспективе начала работ по эколого-экономическому и социоприродному преобразованию степных регионов страны. Достойное место в этой работе несомненно будет занимать проект лесоразведения и повышения лесистости лесодефицитных районов, реализация которого нормализует баланс интересов местного населения, бизнеса и управленческих структур, стимулирует развитие необходимых элементов инфраструктуры.

\section{ЛИТЕРАТУРА}

1. Федеральный закон от 27 декабря 2018 г. № 538-Ф3“0 внесении изменений в Лесной кодекс Российской Федерации и отдельные законодательные акты Российской Федерации в части совершенствования правового регулирования отношений, связанных с обеспечением сохранения лесов на землях лесного фонда и землях иных категорий"

2. Mindlin Y.B., Tikhomirov E. A., Kozhuhov N. I., Nazarenko E. B. The mechanism of introduction of clusters in the Russian Federation // Humanities and Social Sciences Reviews. 2019. T. 7. № 4. C. 767-772.

3. Tikhomirov E.A., Bykovskiy M. A. The current state of the Russian forest industry complex and calculation of costs of forest operations on the basis of activity-based costing in the Russian Federation // FORMEC2019 — Exceeding the Vision: Forest Mechanisation of the Future 6-9 0ctober 2019 — Sopron, Hungary, pp 546

4. Кожухов Н.И., Кострикин В. А., Топчеев А. Н. Инновационный продукт лесной генетики и селекции и его синергетический эффект для лесного хозяйства и смежных отраслей. // Лесотехнический журнал.— 2019.— Т. 9.— № (36).- c. 6-12.

5. Кожухов Н.И., Топчеев А. Н. Некоторые аспекты формирования и устойчивого развития агролесных ландшафтов в условиях Воронежской области // Лесотехнический журнал. - 2019.- - Т. 9.—№ (36).—с. 25-32.

6. Леса России. Состояние лесного фонда. // Федеральное агентство лесного хозяйства — URL: https://roslesinforg.ru/atlas

7. Лесной кодекс России.-Москва.: ВНИИЛМ, 2007. - 856 c.

8. Лесной фонд России.— Москва.: ВНИИЛМ, 2003. - 637 с.

9. Малинецкий Г. Г. Техногенные ресурсы в контексте новой индустриализации России. // Вестник РАН. — 2015.— Т. 85. — № 4. — c. 344-350

10. Приказ от 29 марта 2018 г. N122 «06 утверждении лесоустроительной инструкции».

11. Стратегия инновационного развития Российской Федерации на период до 2020 года // — URL: https://digital.gov.ru/common/upload/2227-pril.pdf 